\title{
A Study on Comparative Examination of the Theme "Power, Authority and Management" in the Social Studies Curriculums of Turkey, Canada (Alberta) and England
}

\begin{tabular}{ccc}
\hline Article Type & Received Date & Accepted Date \\
Research & 3.04 .2019 & 18.07 .2019 \\
\hline
\end{tabular}

Mustafa Yavuz*

\section{Tuğba Cevriye Özkaral**}

\begin{abstract}
This study aims to examine and compare the curricula of Social Studies courses in Turkey, Canada (Alberta) and England in terms of the theme "Power, Authority and Management". It is aimed to determine the similarities and the differences. In the study, qualitative research method was adopted. The source of the data consisted of the social studies curricula applied in Turkey, Canada (Alberta) and England. In the study, the criterion sampling of non-probability sampling methods was used. The findings of the study were obtained using a document analysis. In the analysis of data, descriptive analysis method of qualitative research techniques was used. In the light of the findings obtained in the study, it was seen that right, responsibility, freedom, democracy and constitution were common and were included in the programs of all three countries. It was also determined that the three countries included higher-order thinking skills related to the theme. Based on the research findings, documents such as the Canadian Charter of Rights and Freedoms and the La Grande Paix De Montréal Treaty that are being implemented in other countries may be included in the program in order to give students a universal perspective on laws and rules.
\end{abstract}

Keywords: Curriculum, thematic standard, social studies.

\footnotetext{
* Prof. Dr., Necmettin Erbakan University, Ahmet Keleşoğlu Faculty of Education, Department of Educational Sciences, Konya, Turkey. E-mail: mustafaya2002@gmail.com, https://orcid.org/0000-0001-5697-5120

${ }^{* *}$ Corresponding Author: Assist. Prof. Dr., Necmettin Erbakan University, Ahmet Keleşoğlu Faculty of Education, Department of Turkish and Social Sciences Education, Konya, Turkey. E-mail: ozkaraltugba@gmail.com, https://orcid.org/0000-00034595-816X
} 


\section{“Güç, Otorite ve Yönetim” Temasının Türkiye, Kanada (Alberta) ve İngiltere Sosyal Bilgiler Öğretim Programlarında Karşılaştırmalı Olarak İncelenmesi}

\begin{tabular}{lcc}
\hline $\begin{array}{c}\text { Makale Türü } \\
\text { Araşıtırma }\end{array}$ & $\begin{array}{c}\text { Başvuru Tarihi } \\
3.04 .2019\end{array}$ & $\begin{array}{c}\text { Kabul Tarihi } \\
18.07 .2019\end{array}$ \\
& & \\
Mustafa Yavuz $^{*}$ & Tuğba Cevriye Özkaral $^{* *}$ \\
& $\ddot{O ̈ z}$
\end{tabular}

Bu çalışma; Türkiye, Kanada (Alberta) ve İngiltere Sosyal Bilgiler dersi öğretim programlarının "Güç, Otorite ve Yönetim" teması açısından incelenmesini ve bunların karşılaştırılmasını amaçlamaktadır. Benzerlik ve farklılıkların belirlenmesi hedeflenmektedir. Çalışmada nitel araştırma yöntemi benimsenmiştir. Verilerin kaynağını Türkiye, Kanada (Alberta) ve İngiltere'de uygulanmakta olan sosyal bilgiler kapsamındaki öğretim programları oluşturmaktadır. Araştırmada, olasılığa dayalı olmayan örnekleme yöntemlerinden ölçüt örnekleme kullanılmıştır. Araştırmanın bulguları doküman analizi kullanılarak elde edilmiştir. Verilerin analizinde, bir nitel araştırma tekniği olan betimsel analiz yöntemi kullanılmıştır. Araştırmada elde edilen bulguların 1şığında; hak, sorumluluk, özgürlük, demokrasi ve anayasa konularının ortak olduğu ve üç ülkenin de programında yer aldığı görülmüştür. Aynı zamanda üç ülkenin de temaya ilişkin üst düzey düşünme becerilerine yer vermiş oldukları saptanmıştır. Araştırma bulgularından hareketle; öğrencilere kanun ve kurallar konusunda evrensel bir bakış açısı kazandırmak amacıyla başka ülkelerde uygulanmakta olan Kanada Hak ve Özgürlükler Sözleşmesi; La Grande Paix De Montréal Antlaşması gibi belgelere programda yer verilebilir.

Anahtar Sözcükler: Öğretim programı, tematik standart, sosyal bilgiler.

\footnotetext{
* Prof. Dr., Necmettin Erbakan Üniversitesi, Ahmet Keleşoğlu Eğitim Fakültesi, Eğitim Bilimleri Bölümü, Eğitim Yönetimi Anabilim Dal1, Konya, Türkiye. E-posta: mustafaya2002@gmail.com, https://orcid.org/0000-0001-5697-5120

** Sorumlu Yazar: Dr. Öğretim Üyesi, Necmettin Erbakan Üniversitesi, Ahmet Keleşoğlu Eğitim Fakültesi, Türkçe ve Sosyal Bilimler Eğitimi Bölümü, Sosyal Bilgiler Eğitimi Anabilim Dalı, Konya, Türkiye. E-posta: ozkaraltugba@gmail.com, https://orcid.org/0000-0003-4595-816X
} 


\section{Introduction}

Differentiated from other subjects due to its interdisciplinary nature and with different definitions thanks to this nature, social studies discuss humans and issues concerning humans. Its aim is to educate individuals who are aware of their responsibilities and of social problems and have the qualities required by the globalizing world. The 50 states in the USA have the right to freely determine and implement their curricula, including social studies courses. In addition, it is seen that there is an organization for the purpose of determining national strategies, learning areas and standards related to social studies education. This organization is the National Council of Social Studies (NCSS) (Keskin \& Coşkun Keskin, 2011). NCSS has set training program standards for social studies in 1994, and these standards have been revised in 2010 (NCSS, 2010). According to Doğanay (2008), these standards have been one of the sources that most affected social studies programs in the world. Both in the USA and in many other countries, social studies programs have been revised and developed within the framework of these standards. It is seen that social studies standards consist of three main chapters. These are 10 thematic standards, performance expectations for each standard and learning activities to fulfill them. While thematic standards constitute the scope of social studies, they also help in the determination of objectives and the selection and editing of content in the program. The 10 thematic standards are: Culture; Time, Continuity and Change; People, Places and Environment; Individual Development and Identity; Individuals, Groups and Institutions; Power, Authority and Management; Production, Consumption and Distribution; Science, Technology and Society; Global Bonds; Citizenship Ideals and Practices.

The basis of social studies consists of social sciences. Social sciences are the collection of disciplines that produces knowledge related to humans and for the benefit of humans. Each discipline of social science produces scientific knowledge about a field by examining a dimension of humans. This produced knowledge needs to be brought to the people in various ways, and education constitutes the most important of these ways. Social studies use the scientific knowledge produced in the field of social sciences. In addition, the social studies course enables a holistic approach of students towards social events by combining disciplines related to social sciences. Some of the disciplines that could be considered in social sciences are: anthropology, economics, history, sociology, political science and geography. Political science deals with humans and the subject of management (Stanley, 2001; Doğanay, 2003; Safran, 2008; Kabapınar, 2012; Tay, 2010; Erden, N.d; Sönmez, 2010; Koçoğlu, 2015). One of the ten thematic standards determined by the NCSS, the theme of "Power, Authority and Management" is also closely related to political science.

For the development of the citizenship competencies of our students, they need to understand and comprehend different power, authority and management structures and their development processes. In addition, they need to have sufficient information and be knowledgeable about the evolving functions of these structures both in our country and in other parts of the world. It is considered important to develop the competencies of students on the theme of power, authority and management so that they can become conscious and active citizens regarding subjects such as the functions of management, the scope and limits of authority and how order is ensured in a society. Although different meanings have been imposed on power, which has had an important place in all societies from past to present, it is possible to say that it has meanings such as influencing others or guiding them. In addition, it is a fact that the concept of power is close to and intertwined with the concept of authority.

\section{The Situation in Turkey}

In Turkey, these themes are included under the name of learning areas in the "social studies" programs prepared by the Council of Education of the Ministry of National Education and put in practice in 2005. The theme of "Power, Authority and Management" has been included under the learning area title of "Power, Management and Society". According to the primary school social studies 4-5th grade curriculum, students at 4-5th grades will be able to explore the ways of full participation in society as a conscious citizen, one of the main aims of social studies course, and be aware of their duties and responsibilities with the "Power, Authority and Management" learning area (MEB, 2005a). According to the social studies 6-7th grade curriculum in primary education, this 
learning area helps 6th and 7th grade students explore the ways of full participation in society, be aware of their duties and responsibilities, recognize the concept and process of participation and defend the importance of participation for a democratic life (MEB, 2005b).

A new program was published under the name of "Social Studies Course Curriculum Primary School and Middle School 4th, 5th, 6th and 7th Grades". It is seen that some changes were made in the learning areas. It is seen that the 2018 Social Studies Course Curriculum has been structured within the framework of 7 learning areas and the learning area called "Power, Management and Society" has not been directly included (MEB, 2018b), the subjects of the theme of "Power, Management and Society" were partially included within the scope of the "Active Citizenship" learning area. It is seen that similar features of the 2005 curriculum on the theme of "Power, Management and Society" are prominent in the "Active Citizenship" learning area.

As a result of the literature review, it was determined that the curriculum standards determined by the National Council of Social Sciences (NCSS) of the USA were not adequately addressed in studies. It was found in particular that there was no study on the theme of power, authority and management. In this context, it is thought that this study will contribute to the literature. This study aims to examine and compare the curricula of Social Studies courses in Turkey, Canada (Alberta) and England in terms of the theme "Power, Authority and Management". It is aimed to determine the similarities and the differences. Based on this, it is also aimed to create certain new ideas regarding the Social Studies curriculum applied in our country. In line with the determined general goal, we sought answers to the following subgoals:

What elements does the social studies curriculum of Turkey include under the theme of power, authority and management?

What elements does the social studies curriculum of Canada (Alberta) include under the theme of power, authority and management?

What elements does the England citizenship curriculum include under the theme of power, authority and management?

What are the similarities between the curricula of social studies applied in Turkey, Canada (Alberta) and England in terms of the theme of power, authority and management?

What are the differences between the curricula of social studies applied in Turkey, Canada (Alberta) and England in terms of the theme of power, authority and management?

This study is limited to the curricula of social studies applied in the secondary schools in Turkey, Canada (Alberta) and England in the 2018/2019 academic year.

\section{Method}

Qualitative research method was used in the study. In recent years, the developments in qualitative research methods have contributed greatly to the interpretation of topics researched by qualitative research methods alone or in combination with quantitative research methods (Seggie and Bayyurt, 2017).

\section{Research Sample / Study Group}

In the study, criterion sampling of sampling methods, which are used in qualitative research and not based on probability, was used. In this sampling technique, the sample is determined according to predetermined criteria (Karagöz, 2017). In this context, the curricula in the scope of social studies including elements related to the theme of power, authority and management and that were published in English were identified. The data sources of the study are given in Table 1 below.

Table 1

Data Sources of the Study

\begin{tabular}{ll}
\hline & 2018 \\
Turkey & Social Studies Course Curriculum \\
& Primary and Secondary School $4^{\text {th }}, 5^{\text {th }}, 6^{\text {th }}$ and $7^{\text {th }}$ Grades \\
& 2005 Social Studies Curriculum \\
Canada (Alberta) & K Grade-12
\end{tabular}




\begin{tabular}{|c|c|}
\hline England & $\begin{array}{l}\text { National Program } \\
\text { Citizenship } \\
\text { Key Stage } 2\left(3^{\text {rd }}-6^{\text {th }} \text { grades; } 7-11 \text { ages }\right) / 2015 \\
\text { Key Stage } 3\left(7^{\text {th }}-9^{\text {th }} \text { grades; } 11-14 \text { ages }\right) / 2013\end{array}$ \\
\hline
\end{tabular}

\section{Research Instruments and Procedures}

In qualitative research, there are traditionally three basic forms of gathering information. These are the interviews, observations and examination of documents and works (Merriam, 2013). Document collection may include all kinds of recorded information, written or unwritten. Photographs, budget reports, meeting records, letters, diaries, newspapers, magazines, video and audio recordings, objects and works of art, in short, all types of recorded information, can be considered as a rich database in the research (Buran, 2017). In this research, the data were obtained by "document review". The stages of document review are access to documents, checking the originality (authenticity), understanding the documents, analyzing the data and using the data (Yildirım \& Şimşek, 2011). Documents can be obtained in an electronic format by using a computer or the internet (Baş \& Akturan, 2013). There may be various problems in determining the authenticity of the document. In some cases, the document may be an imitation or may its source may be suspicious (Arthur, Waring, Coe and Hedges, 2017). In these contexts, the curricula that are the documents of this research were obtained in an electronic format by using a computer and the internet and from the official web sites of the ministries of education of the countries to ensure authenticity.

After the documents were obtained, next was the stage of understanding and analyzing them. The relevant parts of the Canada (Alberta) social studies and England citizenship curricula were translated from English to Turkish by the researchers. These translations and original documents were compared and checked by the researchers and a translator. These documents were analyzed within a certain system and in comparison to each other.

\section{Data Analysis}

In the data analysis, the descriptive analysis method, which is a qualitative research technique, was used. According to Yıldırım and Şimşek (2011), the data obtained in descriptive analysis are summarized and interpreted according to predetermined themes. The data may be edited according to the themes presented by the research questions. The aim is to present the findings to the reader in an edited and interpreted manner. The data obtained for this purpose are first described systematically and in a clear manner. Then, these descriptions are explained and interpreted, the cause-effect relationships are examined, and certain conclusions are reached. In this research, the documents, meaning the data obtained through the curricula, were edited according to the themes presented by the research questions and presented to the reader in tables.

\section{Results}

This section includes headings in line with the subgoals of the research. After these headings, the obtained findings are presented in tables.

The Elements Related to the Theme Power, Authority and Management in Turkey Social Studies Curriculum: Rights and Responsibilities, Democracy, Different Regimes, DecisionMaking Process in Management, the Value Given to Women

It is seen that Turkey 2018 Social Studies Course Curriculum is structured around the framework of 7 learning areas and that subjects of the theme "Power, Authority and Management" are included within the "Active Citizenship" learning area. The following tables include the elements of the theme power, authority and management in the Turkey 2018 social studies curriculum. 


\section{Table 2}

The Elements Related to the Theme Power, Authority and Management in Turkey 2018 Social Studies Curriculum

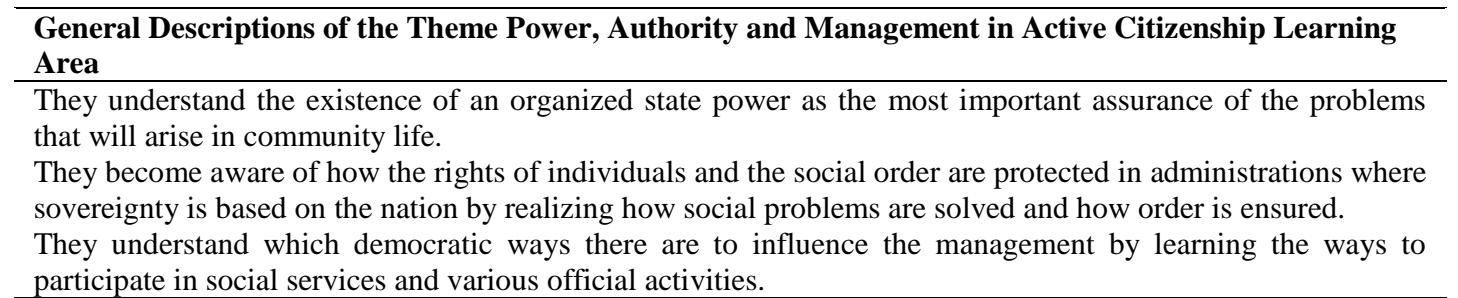

\section{Skills, Gains and Descriptions to be Obtained in Different Class Levels Related to the Theme Power, Authority and Management in Active Citizenship Learning Area}

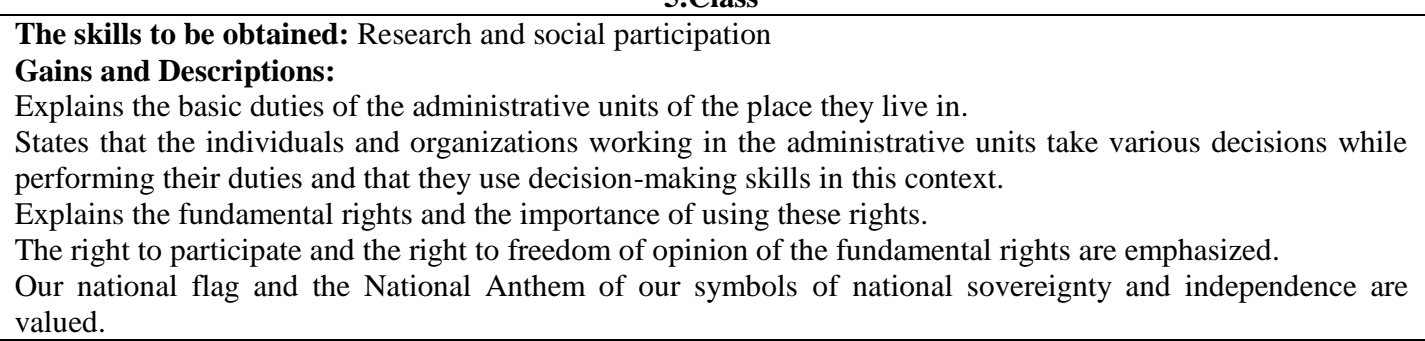
valued.

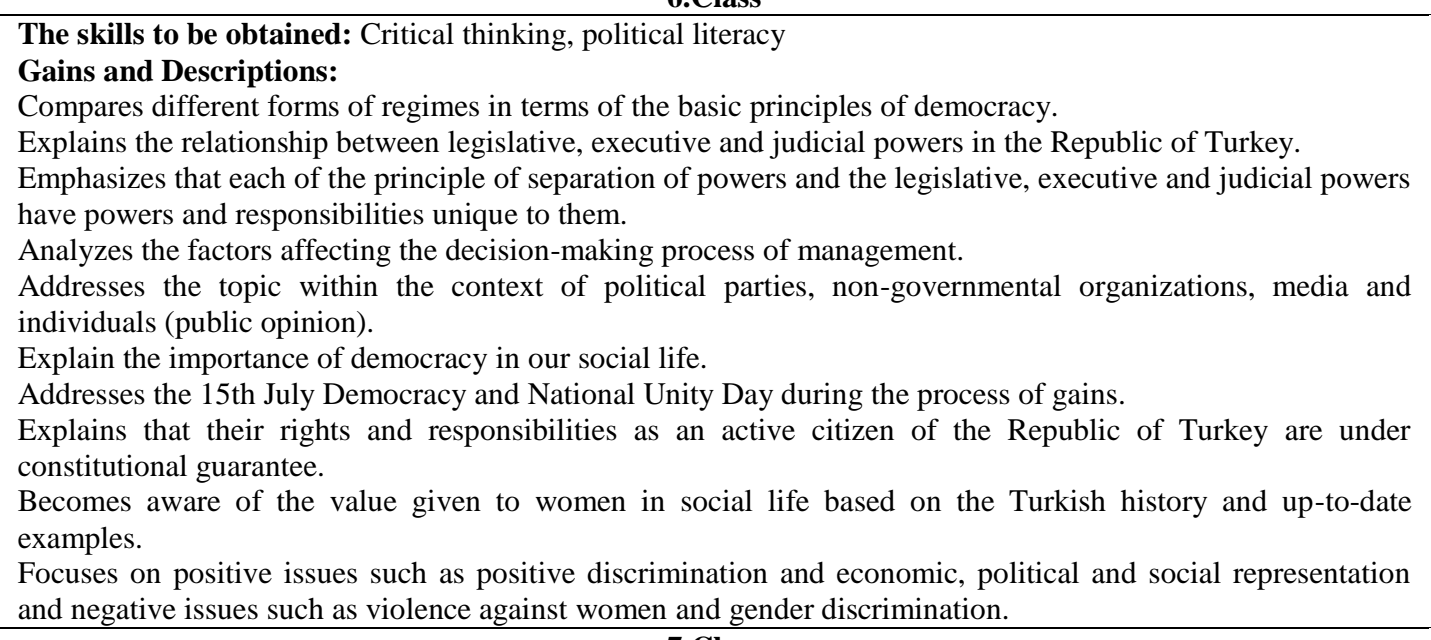

When Table 2 is examined, the elements related to the theme power, authority and management in Turkey 2018 social studies curriculum are seen. Fundamental rights; development of democracy, its principles, importance, contributions of Atatürk to its development, problems in its implementation; comparison of different regimes; separation of powers; the decision-making process of management 
are some of the prominent topics. It is seen that higher-order thinking processes such as problemsolving and critical thinking are given importance. However, it is seen that elements in the dimensions of analysis, synthesis and evaluation are not sufficiently included in the program, based on the gains and descriptions that rather start with the expressions explains and comprehends.

The Elements Related to the Theme Power, Authority and Management in Canada (Alberta) 2005 Social Studies Curriculum: Canadian Charter of Rights and Freedoms; Rights, Freedoms and Responsibilities; Historical Development and Types of Democracy; Constitution; La Grande Paix De Montréal Treaty; Local Governments; State Government Structure and Functions

Canada (Alberta) 2005 social studies curriculum includes six chapters that reflect the interdisciplinary structure of social studies. One of these chapters is "Power, Authority and DecisionMaking". The table below includes the elements related to the theme power, authority and management in Canada (Alberta) 2005 social studies curriculum.

Table 3

The Elements Related to the Theme Power, Authority and Management in Canada (Alberta) 2005 Social Studies Curriculum

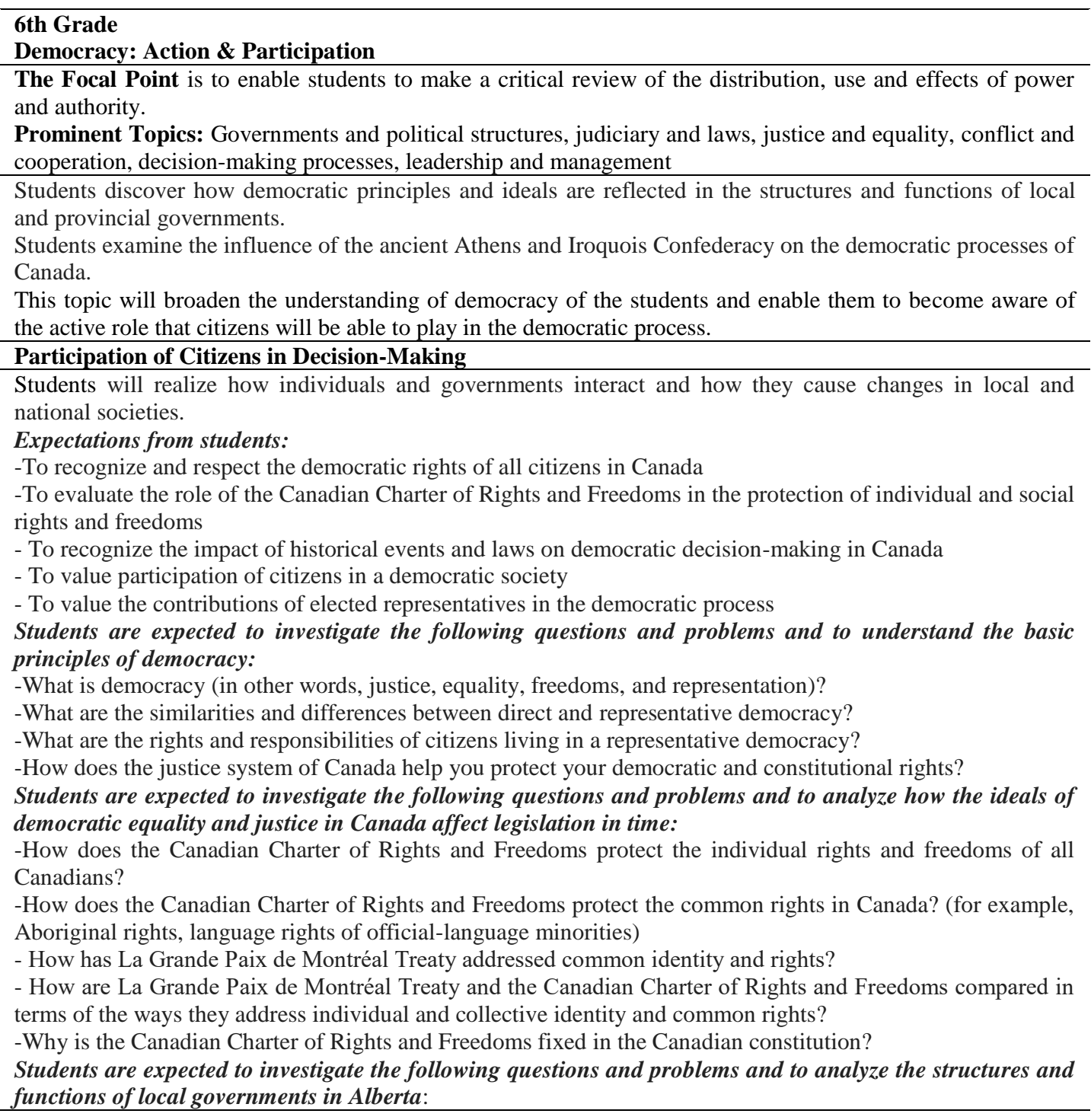




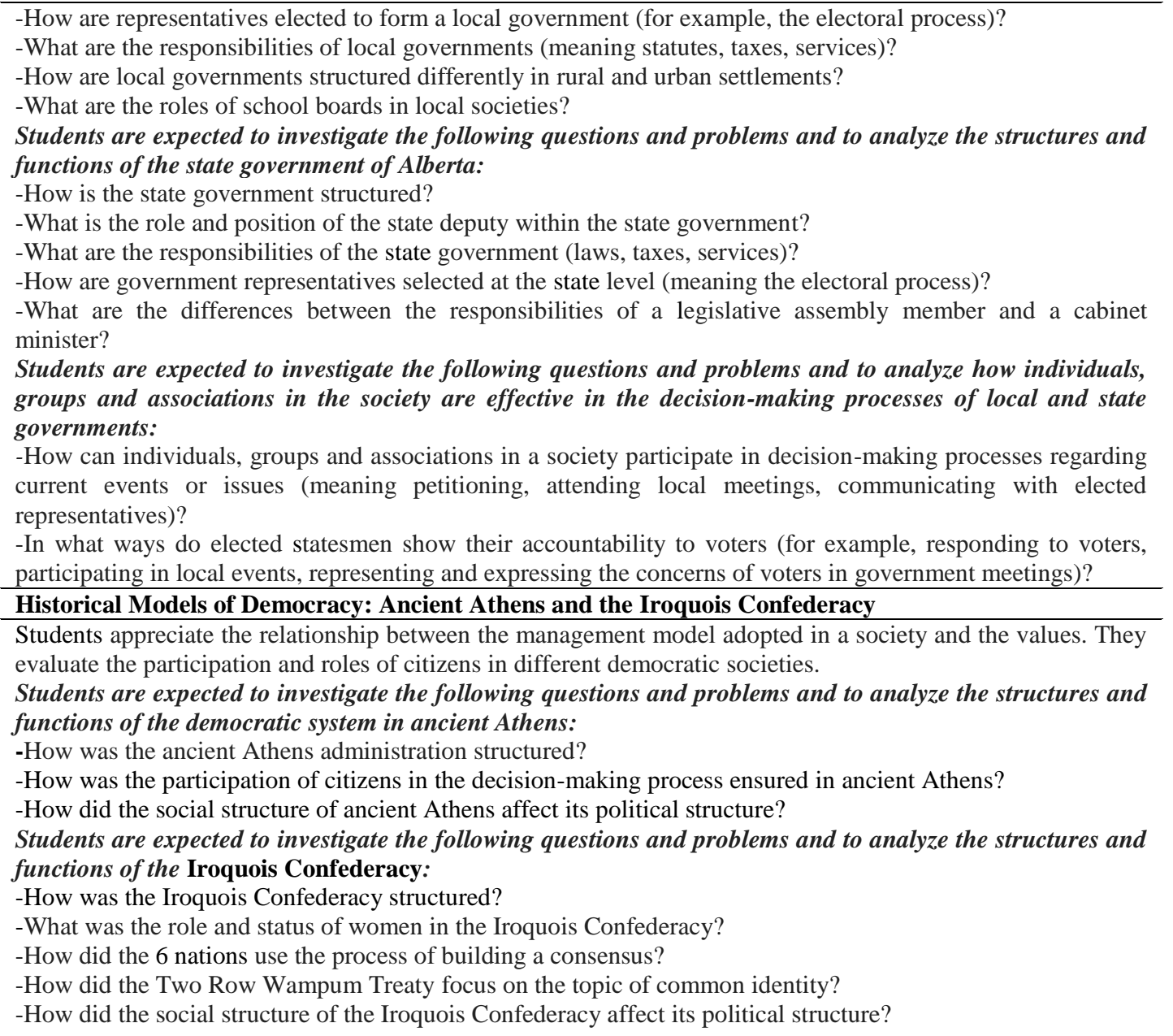

When Table 3 is examined, the elements related to the theme power, authority and management in Canada (Alberta) social studies curriculum are seen. It is worth noting that the country has included these topics under the heading of "power, authority and decision-making". Elements related to theme become concentrated at the 6th grade and under the chapter of democracy.

Students are expected to investigate and analyze some questions and problems. In addition, the focal point is to enable students to make a critical review on the distribution, use and effects of power and authority; therefore, it is thought that there is an effort to develop higher-order thinking skills in students. Government and political structures, judiciary and laws, justice and equality, conflict and cooperation, decision-making processes, and leadership and management are expressed as the prominent topics. Canadian Charter of Rights and Freedoms; rights, freedoms and responsibilities; democracy and its types; constitution; local governments; La Grande Paix de Montréal Treaty; structure and functions of state government; historical development of democracy and the examples of ancient Athens and the Iroquois Confederacy are among the other highlighted topics.

The Elements Related to the Theme Power, Authority and Management in the England Citizenship Curriculum: Laws and Rules; Rights, Responsibilities and Duties; Freedoms; Elections; Democracy; Parliament; Monarchy

It is seen that topics of the theme Power, Authority and Management are included in the National Curriculum of England at the levels of Key Stage $2\left(3^{\text {rd }}-6^{\text {th }}\right.$ grade, $7-11$ ages $)$ and Key Stage $3\left(7^{\text {th }}-9^{\text {th }}\right.$ grade; 11-14 ages) in the citizenship course. The following tables include the elements related to the 
theme Power, Authority and Management at the levels of Key Stage $2\left(3^{\text {rd }}-6^{\text {th }}\right.$ grade, $7-11$ ages $)$ and Key Stage 3 ( $7^{\text {th }}-9^{\text {th }}$ grade; $11-14$ ages $)$ in the England citizenship curriculum.

\section{Table 4}

The Elements Related to the Theme Power, Authority and Management at the Levels of Key Stage 2 ( $3^{\text {rd }} 6^{\text {th }}$ grade, 7-11 ages) in the England Citizenship Curriculum

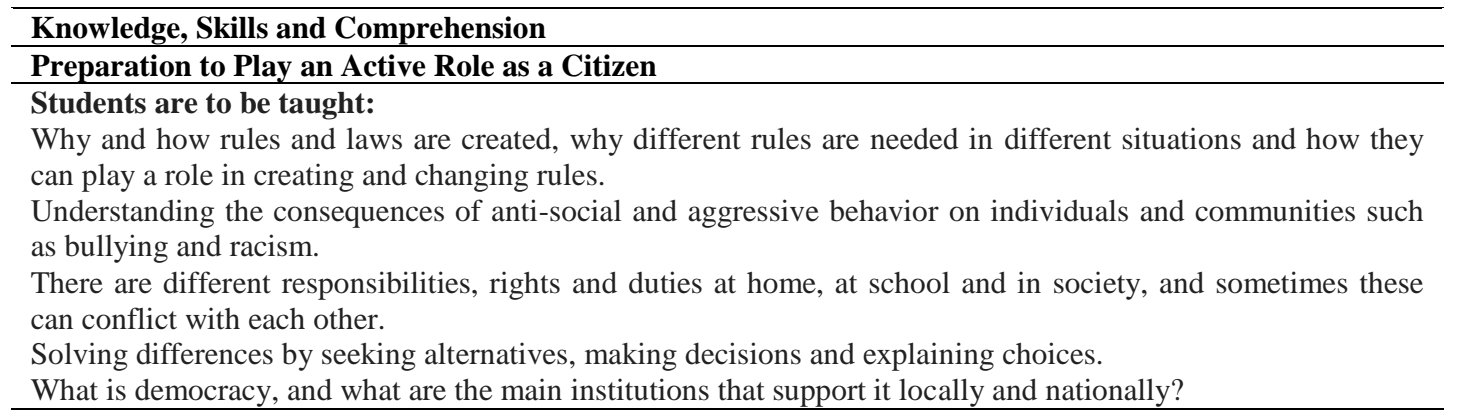

\section{Table 5}

The Elements Related to the Theme Power, Authority and Management at the Level of Key Stage 3 ( $7^{\text {th }}$ - ${ }^{\text {th }}$ grade; 11-14 ages) in the England Citizenship Curriculum

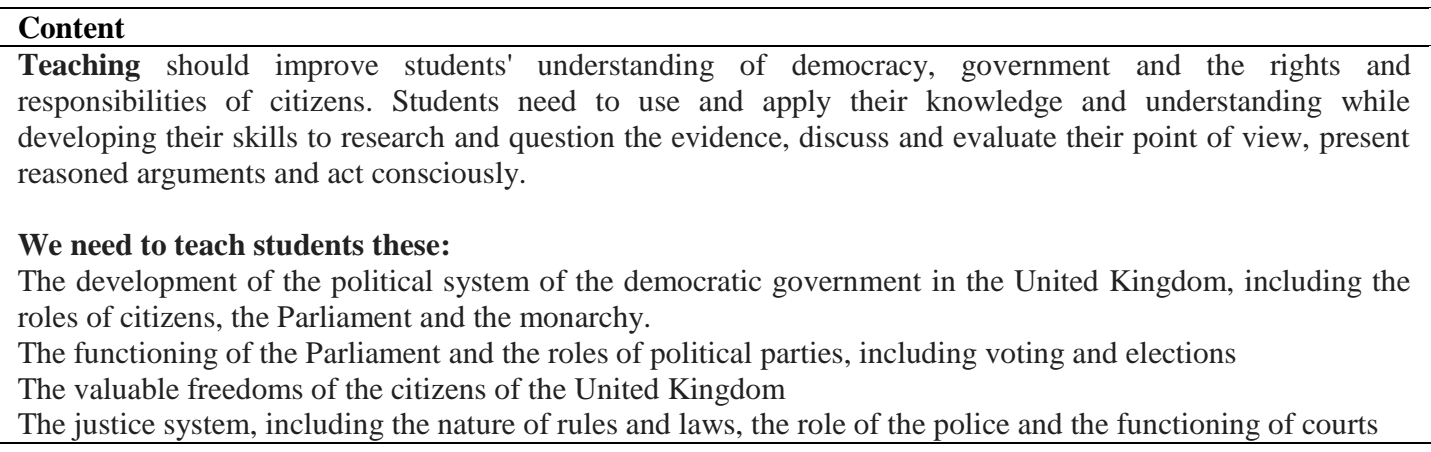

Table 4 and Table 5 include the elements related to the theme power, authority and management at the levels of key stage $2\left(3^{\text {rd }}-6^{\text {th }}\right.$ grade, $7-11$ ages $)$ and key stage $3\left(7^{\text {th }}-9^{\text {th }}\right.$ grade, $11-14$ ages $)$ in the England citizenship curriculum. While the topics of laws, rules, rights, responsibilities, duties, elections and democracy are prominent at the level of key stage $2\left(3^{\text {rd }}-6^{\text {th }}\right.$ grade, $7-11$ ages $)$, topics such as the roles of citizens, parliament, monarchy, elections, political parties, freedoms, rules, laws and the justice system are considered at the level of key stage 3 ( $7^{\text {th }}-9^{\text {th }}$ grade, $11-14$ ages). It is also seen that the development of skills such as researching, questioning, discussing and evaluating points of view, presenting reasoned arguments and acting consciously is considered at the level of key stage 3 ( $7^{\text {th }}-9^{\text {th }}$ grade; $11-14$ ages $)$. 
Similarities and Differences between the Social Studies Curricula Applied in Turkey, Canada (Alberta) and England In Terms of the Theme Power, Authority and Management

\section{Table 6}

Similarities and Differences between the Social Studies Curricula Applied in Turkey, Canada (Alberta) and England In Terms of the Theme Power, Authority and Management

\begin{tabular}{|c|c|c|c|}
\hline & Turkey & Canada (Alberta) & England \\
\hline \multirow{10}{*}{ ELEMENTS } & $\begin{array}{l}\text { Rights, Responsibility, } \\
\text { Freedom } \\
\text { Democracy }\end{array}$ & $\begin{array}{l}\text { Rights, Responsibility, } \\
\text { Freedom } \\
\text { Democracy }\end{array}$ & $\begin{array}{l}\text { Rights, Responsibility, } \\
\text { Freedom } \\
\text { Democracy }\end{array}$ \\
\hline & Constitution & Constitution & Laws and Rules \\
\hline & $\begin{array}{l}\text { Including higher-order } \\
\text { thinking skills related to the } \\
\text { theme } \\
\text { (Problem-solving, critical } \\
\text { thinking) }\end{array}$ & $\begin{array}{l}\text { Including higher-order } \\
\text { thinking skills related to the } \\
\text { theme } \\
\text { (Critical thinking) }\end{array}$ & $\begin{array}{l}\text { Including higher-order } \\
\text { thinking skills related to } \\
\text { the theme } \\
\text { (Researching, } \\
\text { questioning, discussing } \\
\text { and evaluating points of } \\
\text { view, presenting reasoned } \\
\text { arguments and acting } \\
\text { consciously) }\end{array}$ \\
\hline & Different regimes & - & - \\
\hline & The Value Given to Women & - & - \\
\hline & - & Local Governments & - \\
\hline & - & $\begin{array}{l}\text { Canadian Charter of Rights } \\
\text { and Freedoms }\end{array}$ & - \\
\hline & - & $\begin{array}{l}\text { La Grande Paix De Montréal } \\
\text { Treaty }\end{array}$ & - \\
\hline & - & - & Parliament \\
\hline & - & - & Monarchy \\
\hline
\end{tabular}

Table 6 includes the similarities and differences between the social studies curricula applied in Turkey, Canada (Alberta) and England in terms of the theme power, authority and management. It is seen that the topics of rights, responsibilities, freedoms, democracy and constitution are common and included in the curricula of all three countries. It is also worth noting that all three countries include higher-order thinking skills related to the theme. It is also seen that different regimes and the value given to women appear as topics included in our country but are not included in the curricula of other countries. The topics of local governments, the Canadian Charter of Rights and Freedoms and La Grande Paix De Montréal Treaty appear as the different topics included in Canada (Alberta). In England, the topics of parliament and monarchy are included and constitute the difference.

\section{Discussion, Conclusion and Recommendations}

In this study, the social studies curricula of Turkey, Canada (Alberta) and England were examined and compared in terms of the theme of "Power, Authority and Management", one of the ten thematic standards set by NCSS. In the light of the findings obtained in the research; "rights and responsibilities, democracy, different regimes, decision-making process in management, value given to women" were determined as the elements related to the theme of power, authority and management in the social studies curriculum of Turkey. It is determined that higher-order thinking processes such as problem-solving and critical thinking are given importance. However, based on the gains and descriptions ending with expressions such as explains and understands, it is seen that there are expressions at the level of knowledge/remembering, comprehension/understanding in the curriculum and that elements in the dimensions of analysis, synthesis and evaluation are not sufficiently included. 
This is also reflected to the education process. In the study by Yilmaz and Gazel (2017), it was observed that teachers first preferred the questions in the knowledge step of the cognitive domain of Bloom's Taxonomy. The questions in the comprehension step took the second place. In addition, it was determined that the number of questions asked in the dimensions of analysis, synthesis and evaluation were quite low. Whereas the education process also needs to develop thinking skills such as analysis, synthesis, evaluation and association.

In this study, elements related to the theme of power, authority and management in the social studies curriculum of Canada (Alberta) were determined as "The Canadian Charter of Rights and Freedoms; rights, freedoms and responsibilities; historical development and types of democracy; constitution; La Grande Paix De Montréal Treaty; local governments; structure and functions pf state government". It was seen that the elements related to this theme were concentrated at the 6th grade and under the title of democracy. Students are expected to investigate and analyze some questions and problems. In addition, efforts to develop skills such as critical thinking in students within the scope of this theme were observed. According to Özden (2014), critical thinking requires being active, and in this context, it enables us to actively use our intelligence and cognitive skills. From this point of view, students will gain their freedom of thought, feel that they are using their minds and gain the habit of looking at things from different angles.

As a result of the research, elements related to the theme of power, authority and management in the citizenship curriculum of England were determined as laws and rules; rights, responsibilities and duties; freedoms; elections; democracy; parliament; monarchy. It is seen that the development of skills such as researching, questioning, discussing and evaluating points of view, presenting reasoned arguments and acting consciously are also given importance in the curriculum. On the other hand, the topics of different regimes and the value given to women were determined as topics included in our country but not addressed in the curricula of other countries. It is seen that the rights granted to Turkish women during the Republican period have been broadened. Turkish women have gained various rights in the Republican period. For example, while girls and boys began to receive education with the Law on Unification of Education in 1924, men and women first had equal rights with the Civil Code. It happened gradually for women to gain political and social rights in the state. In addition, women were granted rights such as divorce and parental rights with the adoption of the Turkish Civil Code in 1926 (Aydin, 2015). In this context, it is thought that this topic is given a place and importance in the curriculum. In addition, the fact that different regimes are included is important for students to see similar and different aspects of these regimes and to make comparisons.

The topics of local governments, the Canadian Charter of Rights and Freedoms and La Grande Paix De Montréal Treaty were identified as the different topics included in Canada (Alberta). Canada has a federal government along with 10 states and 3 regional administrations (The World Factbook Canada, 2019). As there are states and regional administrations, in other words, due to the administrative structure of the country, local governments are considered to be given importance in the curriculum. The Canadian Charter of Rights and Freedoms includes fundamental rights for all who live in the country and is included in the constitution. Freedom of expression and freedom of religion, democratic rights, free movement and language rights are guaranteed in the charter. In addition, this charter provides protection of the public against discrimination based on gender, race, ethnic origin and physical or mental disability (Government of Canada, 2019). The addressing of the topics of parliament and monarchy in England was observed as a difference. We think that these topics are concentrated on because the United Kingdom, where Wales, Scotland and Northern Ireland and England are member countries, is a parliamentary monarchy.

\section{Based on the findings of the study, some recommendations were made:}

Suggestions towards curriculum developers:

In the 2018 social studies curriculum that is implemented in our country, the gains and descriptions in the content including the theme of power, authority and management are mostly at the level of knowledge/remembering and comprehension/understanding. It is thought that expressions at the level of analysis, synthesis and evaluation should be included. 
In the social studies curriculum of Canada (Alberta), various questions and problems are included instead of gains and descriptions, and students are expected to research and analyze them. In our country, rather than the gains and descriptions, various questions and problems can be included for students to permanently learn the elements related to the theme of power, authority and management. It can be aimed that they make questioning, discussing, analyzes and evaluation on these.

Documents such as the Canadian Charter of Rights and Freedoms and La Grande Paix De Montréal Treaty that are applicable in other countries may be included to give students a universal perspective on laws and rules.

Suggestions towards researchers:

Studies on the other 9 thematic standards set by the NCSS other than the theme of power, authority and management can be carried out.

\section{References}

Arthur, J., Waring, M., Coe, R. \& Hedges, L.V. (2017). Eğitimde Araştırma Yöntemleri ve Metodolojileri [Research Methods and Methodologies in Education]. A. Erözkan and E.Büyüköksüz (Ed.). Ankara: Anı.

Aydın, H. (2015). Meşrutiyet'ten Cumhuriyete Türkiye'de Kadın [Women in Turkey from the Constitutional Monarchy to the Republic]. Current Research in Social Sciences, 1(3), 84-96.

Baş, T. \& Akturan, U. (2013). Nitel Araştırma Yöntemleri [Qualitative Research Methods]. Ankara: Seçkin.

Buran, A. (2017). Nitel Araştırmada Veri Toplama [Data Collection in Qualitative Research]. In F.N.Seggie \& Y.Bayyurt (Ed), Nitel Araştırma Yöntem, Teknik, Analiz ve Yaklaşımları [Qualitative Research Method, Technique, Analysis and Approaches] (pp. 43-58). Ankara: An1.

Department for Education (2013). Citizenship Programmes of Study: Key Stages 3 and 4 National Curriculum in England. Retrieved from https://www.gov.uk/government/publications/nationalcurriculum-in-england-citizenship-programmes-of-study Retrieval date: 16.09.2018.

Department for Education (2015). Citizenship Programmes of Study: Key Stages 1 and 2 National Curriculum in England. Retrieved from https://www.gov.uk/government/publications/citizenshipprogrammes-of-study-for-key-stages-1-and-2 Retrieval date: 08.12.2018.

Doğanay, A. (2003). Sosyal Bilgiler Öğretimi [Social Studies Education]. In C. Öztürk, D. Dilek (Ed.), Hayat Bilgisi ve Sosyal Bilgiler Öğretimi [Life Sciences and Social Studies Education] ( p.16-43 ). Ankara: Pegem Academy.

Doğanay, A. (2008). Çağdaş Sosyal Bilgiler Anlayışı Işığında Yeni Sosyal Bilgiler Programının Değerlendirilmesi [Evaluation of the New Social Studies Curriculum in the Light of the Contemporary Understanding of Social Studies]. Ç.Ü. Sosyal Bilimler Enstitüsü Dergisi [Ç.U. Journal of the Institute of Social Sciences], 17 (2), 77-96. Retrieved from http://dergipark.ulakbim.gov.tr/cusosbil/article/view/5000001271

Erden, M. (n.d). Sosyal Bilgiler Öğretimi [Social Studies Education]. Ankara: Alkım.

Government of Alberta (2005). Social Studies K-Grade 12. Retrieved from http://www.learnalberta.ca/ProgramOfStudy.aspx?lang=en\&ProgramId=564423\#370073 .

Government of Canada (2019). Political and legal institutions. Retrieved from https://www.canadainternational.gc.ca/turkey-turquie/about-a_propos/organizationorganisation. aspx?lang=tur.

Kabapınar, Y. (2012). Kuramdan Uygulamaya Hayat Bilgisi ve Sosyal Bilgiler Öğretimi [Social Studies Teaching from Theory to Practice]. Ankara: Pegem Academy.

Karagöz, Y. (2017). SPSS ve Amos Uygulamalı Nitel-Nicel-Karma Bilimsel Araştırma Yöntemleri ve Yayın Etiği [SPSS and Amos Practical Qualitative-Quantitative-Mixed Scientific Research Methods and Publication Ethics]. Ankara: Nobel. 
Keskin, Y. \& Coşkun-Keskin, S. (2011). Amerika Birleşik Devletleri [United States of America]. In C. Öztürk (Ed.), Farklı Ülkelerin Sosyal Bilgiler Öğretim Programları [Social Studies Curricula of Different Countries](s.73-104). Ankara: Pegem A.

Koçoğlu, E. (2015). Sosyal Bilgiler Eğiminde Temel Disiplinler ve Çalışma Alanları [Basic Disciplines and Fields of Study in Social Studies]. In Ramazan Sever (Ed.), Sosyal Bilgiler Öğretimi [Social Studies Teaching] (p.47-84). Ankara: Nobel.

MEB (2005a). İlköğretim Sosyal Bilgiler Dersi Öğretim Programı, 4-5. Sinıflar [Primary School Social Studies Curriculum, 4th-5th Grades]. Retrieved from http://ttkb.meb.gov.tr Retrieval date: 25.02.2013.

MEB (2005b). İlköğretim Sosyal Bilgiler Dersi Öğretim Programı, 6-7. Sinıflar [Primary School Social Studies Curriculum, 6th-7th Grades]. Retrieved from http://ttkb.meb.gov.tr Retrieval date: 25.02.2013.

MEB (2018b). Sosyal Bilgiler Dersi Öğretim Programı İlkokul ve Ortaokul 4, 5, 6 ve 7. Sınıflar [Social Studies Curriculum Primary School and Secondary School 4th, 5th, 6th and 7th Grades]. Retrieved from http://ttkb.meb.gov.tr Retrieval date: 02.03.2018.

Merriam, S. B. (2013). A Guide to Qualitative Research Design and Practice. Selahattin Turan (Trns. Ed.). Ankara: Nobel.

NCSS (2010). National curriculum standards for social studies: A framework for teaching, learning, and assessment (Bulletin 111). Silver Spring, MD: NCSS.

Özden, Y. (2014). Öğrenme ve Öğretme [Learning and Teaching]. Ankara: Pegem A.

Safran, M. (2008). Sosyal Bilgiler Öğretimine Genel Bakış [An Overview of Social Studies Teaching]. In Bayram Tay, Adem Öcal (Ed.), Özel Öğretim Yöntemleriyle Sosyal Bilgiler Ögretimi [Social Studies Teaching with Special Teaching Methods] (p. 2-16). Ankara: Pegem Academy.

Seggie, F.T. \& Bayyurt, Y. (2017). Nitel Araştırma Yöntemlerine Giriş [Introduction to Qualitative Research Methods]. In F.N.Seggie \& Y.Bayyurt (Ed), Nitel Araştırma Yöntem, Teknik, Analiz ve Yaklaşımları (Qualitative Research Method, Technique, Analysis and Approaches) (pp. 11-22). Ankara: Anı.

Stanley, W.B. (2001). Social Studies: Problems and Possibilities. W.B.Stanley (Ed.) Critical Issues in Social Studies Research for the 21st Century (p.1-13). Greenwich, CT: Information Age.

Tay, B. (2010). Sosyal Bilgiler Öğretiminin Dünü Bugünü ve Yarını [The Past, Present and Future of Social Studies Teaching]. In Refik Turan, Kadir Ulusoy (Ed.) Sosyal Bilgilerin Temelleri [Foundations of Social Studies] (p. 5-19). Ankara: Pegem Academy.

The World Factbook Canada (2019). Retrieved from https://www.cia.gov/library/publications/theworld-factbook/geos/ca.html.

Yıldırım, A. \& Şimşek, H. (2011). Sosyal Bilimlerde Nitel Araştırma Yöntemleri [Qualitative Research Methods in Social Sciences]. Ankara: Seçkin.

Yılmaz, A \& Gazel, A.A. (2017). 4. ve 7. Sinıf Sosyal Bilgiler Derslerinde Sorulan Öğretmen Sorularının Bloom Taksonomisinin Bilişsel Alanına Göre İncelenmesi [Investigation of Teacher Questions in 4th and 7th Grade Social Studies Courses According to the Cognitive Dimension of Bloom's Taxonomy]. Afyon Kocatepe Üniversitesi Sosyal Bilimler Dergisi [Afyon Kocatepe University Journal of Social Sciences], 19(2), 173-186. Retrieved from http://dergipark.gov.tr/akusosbil/issue/34128/378516 . 
